\title{
Stereological analysis of gonads from diploid and triploid fish yellowtail tetra Astyanax altiparanae (Garutti \& Britski) in laboratory conditions
}

\author{
Nivaldo Ferreira do Nascimento ${ }^{1,3}$, Diógenes Henrique de Siqueira-Silva, ${ }^{3,4}$ \\ Matheus Pereira-Santos ${ }^{2,3}$, Takafumi Fujimoto ${ }^{5}$, José Augusto Senhorini ${ }^{3}$, \\ Laura Satiko Okada Nakaghi ${ }^{2}$ and George Shigueki Yasui ${ }^{3}$ \\ Aquaculture Center, São Paulo State University, Jaboticabal, Brazil; Laboratory of Fish Biotechnology, National Center for \\ Research and Conservation of Continental Fish, Chico Mendes Institute of Biodiversity Conservation, Rodovia Pref. Euberto \\ Nemésio Pereira de Godoy, Pirassununga, Brazil; Universidade do Sul e Sudeste do Pará, Lote especial - Nova Marabá, \\ Marabá, Brazil; and Faculty of Fisheries Sciences, Hokkaido University, Hakodate, Japan
}

Date submitted: 13.03.2017. Date accepted: 18.05.2017

\section{Summary}

This study aimed to examine the gonadal morphology of diploid and triploid fish through stereological analysis. Triploid individuals were obtained after temperature shock $\left(40^{\circ} \mathrm{C}\right.$ for $\left.2 \mathrm{~min}\right)$ at $2 \mathrm{~min}$ postfertilization and reared until 175 days post-fertilization (dpf). Intact eggs were used to obtain the diploids. Gonads were collected for histological analysis at 83, 114, 144 and $175 \mathrm{dpf}$. Diploid females and males presented normal oogenesis and spermatogenesis through all the experimental period. Conversely, stereological analysis revealed that triploid females were sterile and oogonia were the prevalent cell type in the ovaries. Triploid males presented increased amounts of spermatocyte cysts and a large area of lumen when compared with diploids and in addition the amount of spermatozoa was lower than that observed for diploids. However, some triploid males presented spermatogenesis similar to diploids. Therefore, we concluded that triploidization is an interesting alternative to produce sterile individuals in A. altiparanae.

Keywords: Chromosome set manipulation, Fish reproduction, Germ cells, Growth, Sterility

\section{Introduction}

The rearing of triploid sterile fish is an interesting alternative to aquaculture (Piferrer et al., 2009; Arai,

\footnotetext{
${ }^{1}$ All correspondence to: Nivaldo Ferreira do Nascimento. Aquaculture Center, São Paulo State University, Via de Acesso Prof. Paulo Donato Castellane s/n, Jaboticabal, SP 14884-900, Brazil. E-mail: nivaldotec@yahoo.com.br

${ }^{2}$ Aquaculture Center, São Paulo State University, Via de Acesso Prof. Paulo Donato Castellane s/n, Jaboticabal, SP 14884-900, Brazil.

${ }^{3}$ Laboratory of Fish Biotechnology, National Center for Research and Conservation of Continental Fish, Chico Mendes Institute of Biodiversity Conservation, Rodovia Pref. Euberto Nemésio Pereira de Godoy, Pirassununga, SP 13630-970, Brazil.

${ }^{4}$ Universidade do Sul e Sudeste do Pará - UNIFESSPA, Folha 31, Quadra 07, Lote especial - Nova Marabá, Marabá, PA 68507-590, Brazil.

${ }^{5}$ Faculty of Fisheries Sciences, Hokkaido University, 3-1-1 Minato-cho, 041-8611, Hakodate, Japan.
}

2001), as the deleterious aspects of early maturation (e.g. decreased growth and survival) may be avoided (Taranger et al., 2010). In sterile fish, the energy used for gonadal development in diploids (especially females) are deviated for somatic tissue in triploids, with increased growth and carcass yield (Dunham, 2004; Golpour et al., 2016; Nascimento et al., 2017). As the reproductive capacity of sterile triploids is extremely reduced, it also may reduce the impacts of accidental escapes into the wild population (Benfey, 2015). Additionally, the novel surrogate technologies, including germ-cell transplantation, requested a sterile host, and then triploid fish may be used (Yamaha et al., 2007), as previously observed by the production of trout offspring from triploid salmon (Okutsu et al., 2007).

In the neotropical region, however, very few studies have focused on triploid induction in fish but some protocols exist like for the silver catfish Rhamdia quelen (Huergo \& Zaniboni-Filho, 2006) and the 
yellowtail tetra Astyanax altiparanae (Adamov et al., 2016). Astyanax altiparanae is a small characin that presents intertidal spawning, bred throughout a year and presents early sexual maturity at approximately 4 months (Garutti, 2003; Porto-Foresti et al., 2010). Additionally, as it presents great importance to aquaculture, it becomes an interesting model for both basic and applied studies (de Siqueira-Silva et al., 2015; Yasui et al., 2015).

With this purpose, we first developed an in vitro fertilization (IVF) protocol (Yasui et al., 2015) for A. altiparanae. The protocol supported important studies on early development such as the moment of the second-polar body extrusion (dos Santos et al., 2016), which made it possible to determine the adequate timing for subsequent induction of triploid individuals (Adamov et al., 2016). Recently, Nascimento et al. (2017) showed that triploid females are sterile and presents increased carcass yield. However, little difference was observed within males. Despite such work, the authors have performed histological analysis, as more detailed studies on gonad morphology are important for a better understanding of the biology and to confirm the sterility in triploid fish. Although previous works have also attempt to study to evaluate the reproductive biology in other related species (De Carvalho et al., 2009; Dala-Corte \& Azevedo, 2010; Galvão et al., 2016), there is not a reference in order to assess reproductive ability in this species. Additionally, the pattern of stereological observation within diploids and triploids may be an interesting approach to evaluate sterilization quantitatively in fish. Therefore, the aim of this study was to examine the gonad morphology of diploid and triploid fish through stereological analysis.

\section{Materials and Methods}

\section{Ethics}

All the procedures were performed in line with the Guide for the Care and Use of Laboratory Animals in São Paulo State University (UNESP/CEUA 07919/14).

\section{Origin of broodstock and triploid induction}

We used three separately couples of A. altiparanae provided from different ponds at the Instituto Chico Mendes de Conservação a Diversidade (ICMBio/CEPTA), Pirassununga City, São Paulo State, Brazil. The procedures of artificial fertilization were performed according to Yasui et al. (2015). Briefly, mature females and males were injected with a single dose of carp pituitary gland at $3 \mathrm{mg} / \mathrm{kg}$ for both males and females. Ten hours afterwards, fish were anesthetized in menthol $\left(\sim 100 \mathrm{mg} \mathrm{l}^{-1}\right.$, Êxodo Científica, Brazil) and the semen was collected using a $1000 \mu \mathrm{l}$ pipette (Eppendorf, Hamburg, Germany) and immediately transferred to a $1.5 \mathrm{ml}$ tube containing $400 \mu \mathrm{l}$ of modified Ringer solution $(128.3 \mathrm{mM} \mathrm{NaCl}$, $23.6 \mathrm{mM} \mathrm{KCl}, 3.6 \mathrm{mM} \mathrm{CaCl}, 2.1 \mathrm{mM} \mathrm{MgCl}_{2}$ ), mixed by gently pipetting and stored at $2.5^{\circ} \mathrm{C}$. Oocytes from females were stripped onto a Petri dish (90 mm diameter) covered by polyvinylidene chloride film (Saran wrap, Alpfilm, São Paulo, Brazil). For fertilization, $70 \mu \mathrm{l}$ of the diluted semen was added on the oocytes and the gametes were activated by addition of $5 \mathrm{ml}$ of water. This procedure was performed separately from each couple, generating three batches of eggs that was considered as replicates.

\section{Triploid induction and rearing}

Each fertilized group of eggs was divided into two aliquots. One was kept intact and served as a control group and the other was heat shocked to induce triploid at $40^{\circ} \mathrm{C}$, for $2 \mathrm{~min}$ at $2 \mathrm{~min}$ post-fertilization (Adamov et al., 2016). The eggs from each cross were incubated separately in six 40-1 aquarium (three for diploids and three for triploids) for hatching and subsequent larval rearing. The resultant larvae were initially fed exclusively with Artemia franciscana nauplii until 30 days post-fertilization. At this moment, each group of fish were transferred to larger aquariums $(125 \mathrm{~L})$ in a recirculation system, with the temperature set at $28^{\circ} \mathrm{C}$ and $12 \mathrm{~h}$ of light. The stocking density was adjusted to 120 fishes per aquarium that were fed twice a day with a commercial pellet $(1 \mathrm{~mm})$ containing $45 \%$ of crude protein (until apparent satiation), until the end of the experiment.

\section{Samples and histological analysis}

At 83, 114, 144 and 175 days post-hatching (dph), 10 fish from each aquarium were randomly collected and euthanized in menthol ( $100 \mathrm{mg} \mathrm{l}^{-1}$, Êxodo Científica, Brazil). The gonads were dissected, fixed in Bouin's fixative for $24 \mathrm{~h}$ and stored in $70 \%$ ethanol prior to histological processing. Samples were subsequently dehydrated trough increasing concentrations series of ethanol, cleared in xylene, embedded into paraffin blocks, sectioned at $5 \mu \mathrm{m}$ on a microtome (Leica RM2235, Nussloch, Germany) equipped with steel blade (Leica 818, Nussloch, Germany), and sections were then stained with hematoxylin and eosin.

\section{Stereological analysis}

Stereological analyzes used an 825-intersection grid (ImageJ software) on a section from the midgonad 
region. Each grid was considered a field, and three fields (2475 points) were randomly selected and examined under $\times 200$ magnification on a microscope (Nikon-Eclipse Ni, Tokyo, Japan) for each fish. Digital images were captured with a CCD camera (Nikon DSRi2, Nikon, Tokyo, Japan) and analyzed with NIS-Ar Elements software (Nikon, Tokyo, Japan). Spermatogonia, spermatocytes, spermatid, spermatozoa, interstitial tissue, and lumen without cells were counted for males. Oogonia, primary growth oocyte, secondary growth oocyte, vitellogenic oocyte, interstitial tissue and atresic oocyte were counted for females. Different cell types were identified based on the study by Schulz et al. (2010) for male and QuaggioGrassiotto et al. (2011) for female.

\section{Flow cytometry}

Flow cytometric analysis from somatic tissue (dorsal fin) were performed in order to confirm the ploidy status of each individual. The relative DNA content and ploidy status of each fish was estimated by comparison with diploids controls, according to Nascimento et al. (2017). The samples were placed into a $1.5 \mathrm{ml}$ macrotube containing $100 \mu \mathrm{l}$ of lysis solution (9.53 mM MgSO4.7H2O, $47.67 \mathrm{mM} \mathrm{KCl,}$ $15 \mathrm{mM}$ Tris, $74 \mathrm{mM}$ sucrose, $0.8 \%$ Triton $\mathrm{X}-100$ ) for $10 \mathrm{~min}$, and then stained using $800 \mu \mathrm{l}$ of $4^{\prime}, 6-$ diamidino-2-phenylindole dihydrochloride-DAPI (1 $\mu \mathrm{g} \mathrm{ml}^{-1}$ of DAPI in Dulbecco's phosphate buffered saline). The samples were filtered through $30-\mu \mathrm{m}$ nylon mesh and analyzed by flow cytometry (CyFlow Ploidy Analyzer, Partec, GMBh, Germany).

\section{Statistical analysis}

The results are expressed as mean \pm standard error. Data were checked for normality using the Lilliefors test $(5 \%)$. Data expressed as percentages were transformed in order to fit the assumptions of statistical variance homogeneity using the Levene test (Brown \& Forsythe, 1974) and then compared by paired $t$-test $(5 \%)$, considering the effect of ploidy in each time separately. Analysis was performed using the software STATISTICA (Version 10.0, Statsoft, Tulsa, USA).

\section{Results}

\section{Females}

As expected, diploid females presented normal oogenesis during all the experimental period (Figs 1 and $2 A)$. However, triploid females presented impaired gonads (Figs 1 and 2B). Triploid females present greater numbers of oogonia at $83 \mathrm{dph}(P=0.0436$; $27.88 \pm 22.88 \%), 114 \mathrm{dph}(P=0.0000 ; 82.32 \pm 1.79 \%)$, $144 \mathrm{dph}(P=0.0000 ; 45.65 \pm 8.82 \%)$ and $175 \mathrm{dph}$ $(P=0.0000 ; 76.42 \pm 5.78 \%)$; when compared with diploids $(14.61 \pm 5.39 \%, 4.95 \pm 5.51 \%, 0 \%$ and $1.86 \pm$ $1.17 \%$, respectively). The numbers of oocytes in primary growth were significantly higher in diploid females at $83 \mathrm{dph}(P=0.0000 ; 61.99 \pm 5.39 \%)$ and $114 \mathrm{dph}(P=0.0013 ; 7.83 \pm 1.78 \%)$; when compared with triploid fish $(36.01 \pm 52.49 \%$ and $2.27 \pm$ $0.77 \%$, respectively). Diploid females present higher percentages of secondary growth oocytes at $83 \mathrm{dph}$ $(P=0.0266 ; 2.92 \pm 0.94 \%)$ than that observed for triploid fish $(0 \%)$. Vitellogenic oocytes numbers were significantly higher in diploid females at $83 \mathrm{dph}(P=$ $0.0133 ; 7.54 \pm 2.69 \%), 114 \mathrm{dph}(P=0.0000 ; 79.61 \pm$ $5.66 \%), 144 \mathrm{dph}(P=0.0000 ; 83.04 \pm 3.50 \%)$ and 175 dph $(P=0.0000 ; 86.07 \pm 3.93 \%)$; when compared with triploid fish $(0 \%, 1.14 \pm 0.97 \%, 31.16 \pm 8.66 \%$ and $5.04 \pm 3.64 \%$, respectively). Triploid females present higher area occupied by interstitium at $83 \mathrm{dph}(P=$ $0.0000 ; 36.12 \pm 24.19 \%)$, $114 \mathrm{dph}(P=0.0000 ; 13.50 \pm$ $1.46 \%), 144 \mathrm{dph}(P=0.0180 ; 11.46 \pm 1.84 \%)$ and 175 dph $(P=0.0000 ; 12.51 \pm 2.27 \%)$; when compared with diploid fish $(12.94 \pm 2.35 \%, 6.04 \pm 0.97 \%, 10.52 \pm 2.42 \%$ and $4.59 \pm 0.70 \%$, respectively). Besides the prevalence of oogonia, four triploid females presented sporadic vitellogenic oocytes.

\section{Males}

While diploid males presented a regular spermatogenesis (Figs $2 \mathrm{C}$ and 3), triploid males present an impaired gonad development (Figs $2 D$ and 3 ). The numbers of spermatogonia were significantly higher in diploid males at $175 \mathrm{dph}(P=0.0005 ; 5 \pm 0.58 \%)$ than that observed for triploid fish $(2.30 \pm 0.27 \%)$. Triploid males present significantly higher amounts of spermatocytes at $114 \mathrm{dph}(P=0.0000 ; 69.36 \pm$ $1.71 \%), 144 \mathrm{dph}(P=0.0062 ; 59.05 \pm 3.86 \%)$ and $175 \mathrm{dph}(55.87 \pm 3.51 \%)$; when compared with diploid fish $(27.54 \pm 38.66 ; 5.23 \%$ and $28 \pm 2.45 \%)$. Spermatid cells were significantly greater in diploid males at $114 \mathrm{dph}(P=0.0000 ; 6.43 \pm 0.68 \%), 144 \mathrm{dph}(P=$ $0.0002 ; 2.49 \pm 0.50 \%)$ and $175 \mathrm{dph}(P=0.0000 ; 4 \pm$ $0.38 \%)$; in comparison with triploid fish $(1.05 \pm 0.30 \%$; $0.99 \pm 0.25 \%$ and $0.52 \pm 0.13 \%$ ). Diploid males present significantly increased area occupied by spermatozoa at $83 \mathrm{dph}(P=0.0000 ; 12.22 \pm 2.22 \%), 114 \mathrm{dph}(P=$ $0.0000 ; 46.38 \pm 3.57 \%), 144 \mathrm{dph}(P=0.0000 ; 42.29 \pm$ $5.30 \%)$ and $175 \mathrm{dph}(P=0.0000 ; 47 \pm 3.60 \%)$; when compared with triploid fish $(1.44 \pm 0.45 \% ; 2.80 \pm$ $1.16 \% ; 4.34 \pm 2.20 \%$ and $16.33 \pm 4.53 \%$ ). Increased area occupied by interstitium were observed for diploid males at $114 \mathrm{dph}(P=0.0012 ; 6.72 \pm 1.24 \%)$ than that verified in triploid fish $(3.55 \pm 0.38 \%)$. However, at 


\section{DIPLOID}
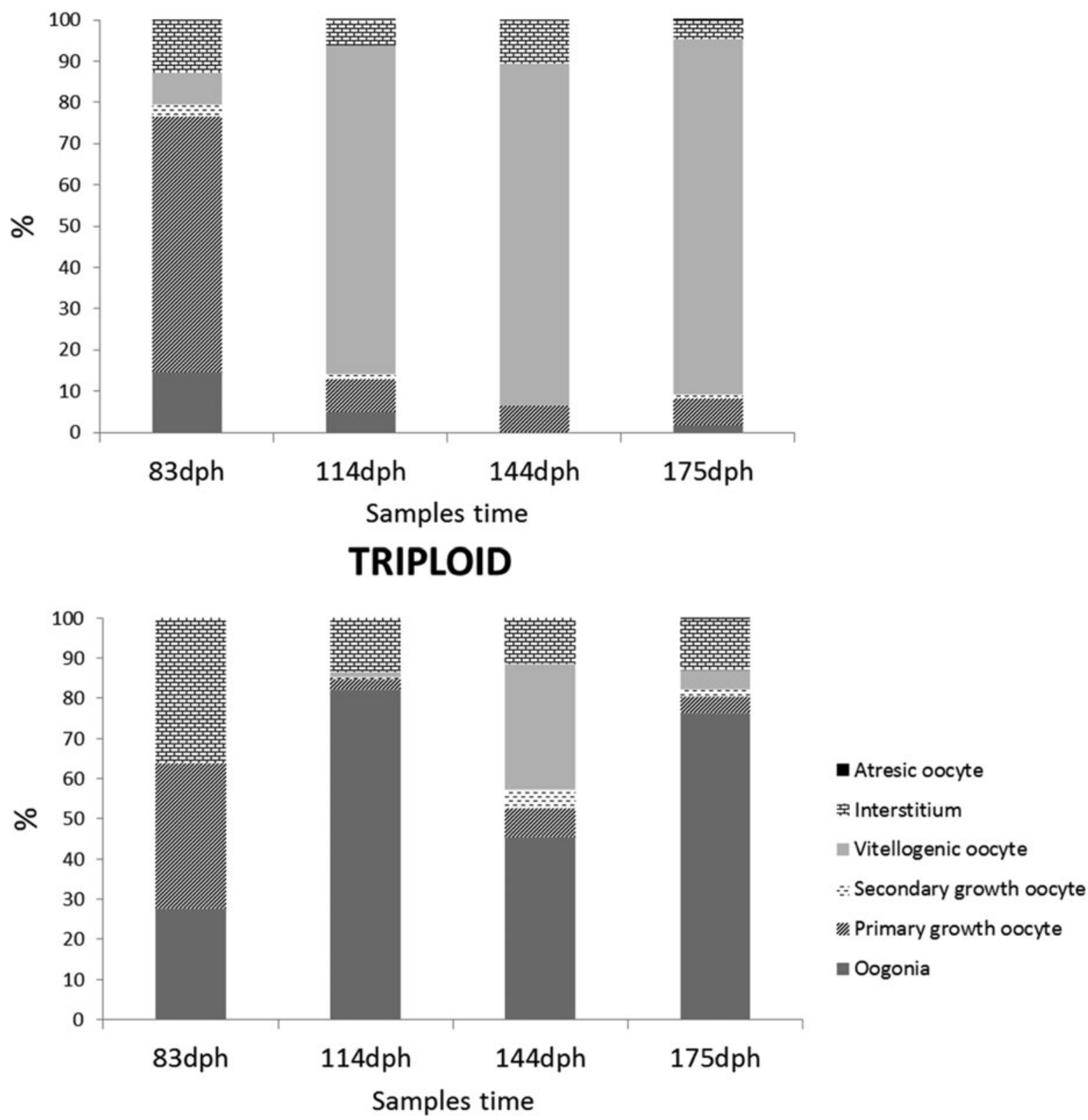

Figure 1 Stereological analysis of A. altiparanae ovarium from diploid (2n) and triploid (3n) fish. Triploid females showed impaired gonad development with prevalence of oogonia.

$175 \mathrm{dph}$, triploid males present higher area occupied by interstitium $(P=0.0000 ; 4.42 \pm 0.39 \%)$ when compared with diploid fish $(3.00 \pm 0.24)$. Triploid males present higher percentages of luminal area at 114 dph $(P=0.0000 ; 19.48 \pm 1.17 \%), 144 \mathrm{dph}(P=0.0000$; $28.70 \pm 3.73 \%)$ and $175 \mathrm{dph}(P=0.0015 ; 20.55 \pm 2.07 \%)$; when compared with diploid fish $(10.20 \pm 0.88 \%, 8.74$ $\pm 2.60 \%$ and $13 \pm 1.38 \%$ ). Besides the impaired gonad development, seven triploids males present identical histology compared with diploid fish, with the full of spermatozoa in the lumen.

\section{Discussion}

In this study we have shown that triploidy impaired gonadal development in both $A$. altiparanae females and males. In triploid fish, sterility is more evident in females (Piferrer et al., 2009), as observed for Atlantic cod (Gadus morhua; Feindel et al., 2011), grass puffer (Takifugu niphobles; Hamasaki et al., 2013) and rainbow trout (Oncorhynchus mykiss; Han et al., 2010). In $A$. altiparanae, the gonads from triploid females were immature and full of oogonia, therefore we 

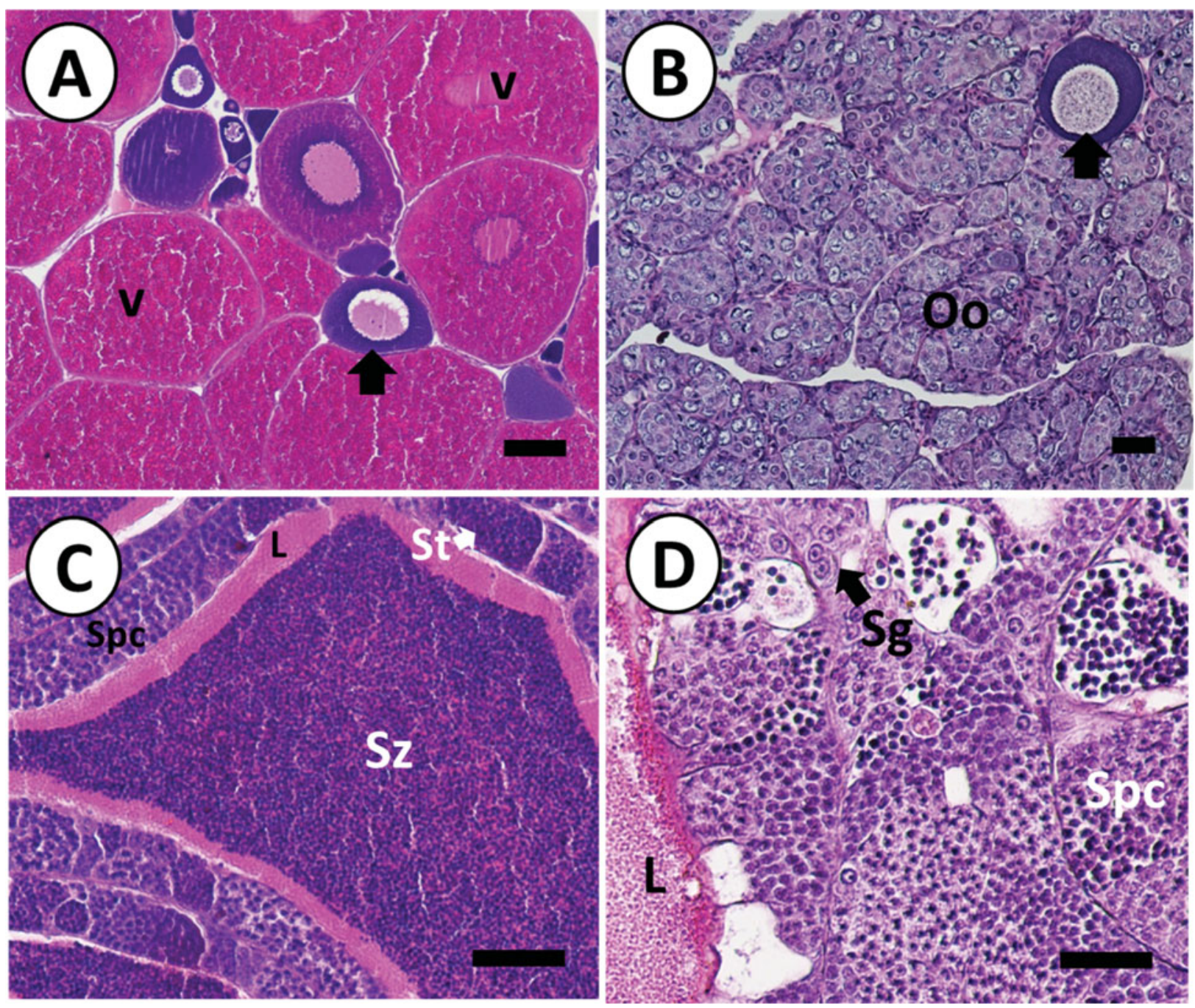

Figure 2 Ovarian and testis histology of diploid and triploid Astyanax altiparanae at $175 \mathrm{dph}$. (A) Mature ovaries from diploid females. (B) Ovaries from triploid females. (C) Testis of diploid males. (D) Testis of triploid males. Oo: oogonia nests; arrows: pre-vitellogenic oocytes; v: vitellogenic oocytes. Sg: spermatogonia; Spc: spermatocytes; St: spermatids; Sz: spermatozoa. Scale bars $(A, C, D) 100 \mu \mathrm{m} ;(B) 40 \mu \mathrm{m}$.

proposed that this stage may be used as a reference to assume sterility in the yellowtail tetra. A few sporadic vitellogenic oocytes were verified in gonads of some females, such conditions do not ensure subsequent ovulation and reproduction, therefore we confirmed that triploid females were then sterile as stated by Nascimento et al. (2017). Additionally, such oocytes are probably aneuploid (Piferrer et al., 2009) and nonviable, as observed for grass puffer (Takifugu niphobles) (Hamasaki et al., 2013).

In triploid males, we observed a strong impairment of gonad development, with the prevalence of lumen and spermatocyte cells. Similar results were observed in Heteropneustes fossilis (Tiwary et al., 2000) and sea bass Dicentrarchus labrax (Felip et al., 2001). In males of sea bass Dicentrarchus labrax (Felip et al., 2001) and seabream Sparus aurata (Haffray et al., 2005), triploidy severely affect meiosis II, when the secondary spermatocytes differentiate into spermatids. It is probable that the same process occurs in A. altiparanae, because most triploid males showed prevalence of spermatocytes, which is the last diploid germ-cell lineage during spermatogenesis.

Some triploid males presented with the same morphology of diploids, with large amounts of spermatozoa, as observed in other species of teleost such as Tinca tinca (Linhart et al., 2006) and Misgurnus anguillicaudatus (Fujimoto et al., 2008). The spermatozoa of triploid males are generally aneuploid and nonmotile (Peruzzi et al., 2009; Feindel et al., 2010). Further studies are necessary to evaluate the ploidy status and fertility capacity of triploid males. Therefore, contrary with the results from females, the sterility of A. altiparanae triploid males could not be confirmed. 


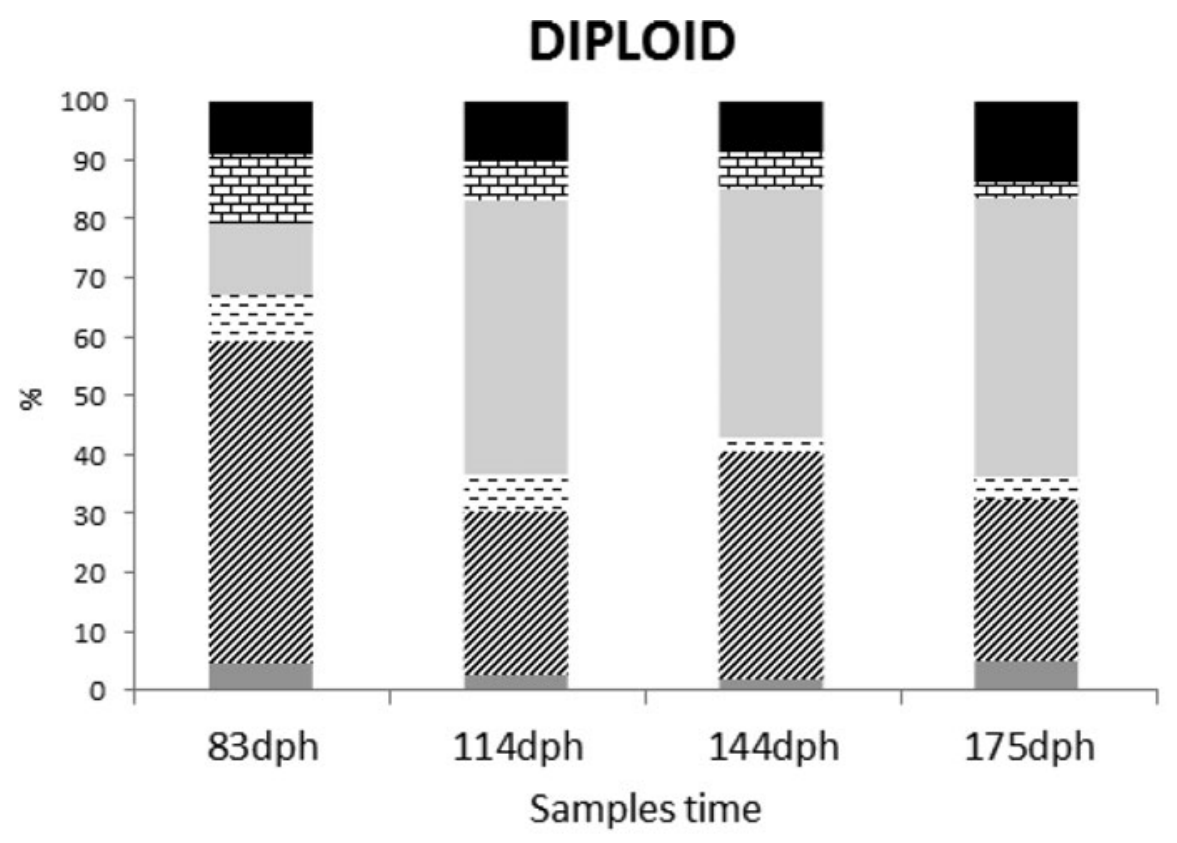

TRIPLOID

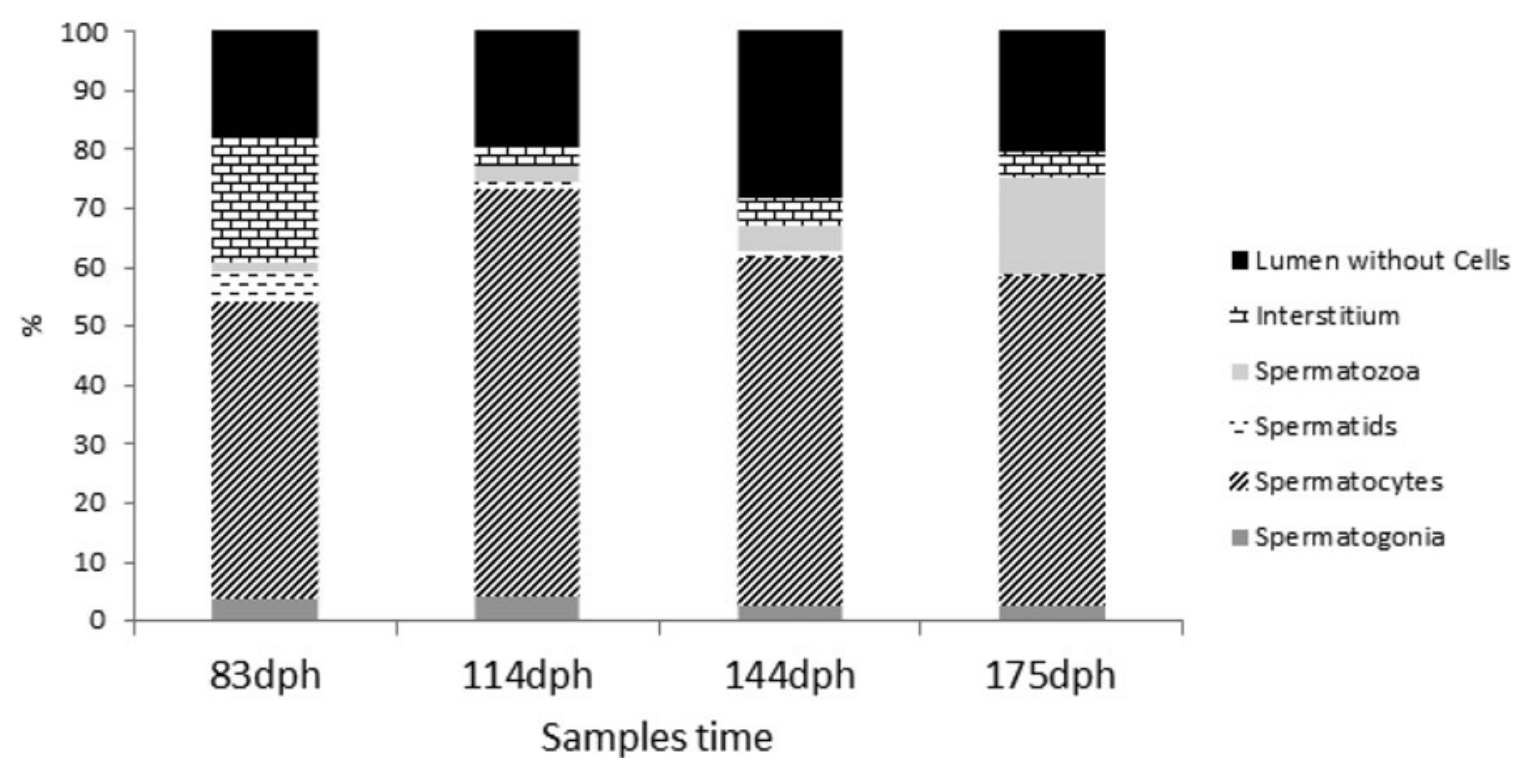

Figure 3 Stereological analysis of A. altiparanae testis from diploid (2n) and triploid (3n) fish. Triploid males showed impaired gonad development with prevalence of spermatocytes.

Sterile fish might be used as the host in germcell transplantation approaches, as shown by Okutsu et al. (2007), by successful production of rainbow trout offspring from sterile triploid salmon. Our results indicated that triploid female A. altiparanae fish may be used in such types of experiments. Additionally, due to the increased carcass yield (Nascimento et al., 2017), triploid fish could be interesting for use in aquaculture and will also guarantee a more sustainable production, as the effects of fish escaping are reduced.
Therefore, as females are sterile and males present with reduced gonad development, we concluded that the $A$. altiparanae triploid fish is an interesting alternative choice for aquaculture production and germ-cell transplant experiments.

Moreover, considering that $A$. altiparanae females are larger than males and present increased growth performance, the production of monosex sterile triploid female will be a useful procedure for aquaculture. In conclusion, an effective method that confirms the 
sterility in A. altiparanae females was developed in this study. The applicability of this technique for both basic and applied sciences needs to be considered in future studies.

\section{Acknowledgements}

The authors thank the Conselho Nacional de Desenvolvimento Científico e Tecnológico (CNPq 130417/2013-0) for the Master's scholarship; the Centro de Aquicultura da UNESP (CAUNESP), FAPESP (JP-FAPESP 2010/17429-1), CEPTA/ICMBio for providing the fish; and the FCAV/UNESP (Faculdade de Ciências Agrárias e Veterinárias) for assistance with the histological analysis.

\section{References}

Adamov, N., Nascimento, N.F., Maciel, E.C.S., PereiraSantos, M., Senhorini, J.A., Nakaghi, L.S.O., Guerrero, A.H.M., Fujimoto, T. \& Yasui, G.S. (2016). Triploid induction in the yellowtail tetra Astyanax altiparanae using temperature shock: tools for conservation and aquaculture. J. World Aquacult. Soc.. doi: 10.1111/jwas.12390.

Arai, K. (2001). Genetic improvement of aquaculture finfish species by chromosome manipulation techniques in Japan. Aquaculture 197, 205-28.

Benfey, T.J. (2015). Effectiveness of triploidy as a management tool for reproductive containment of farmed fish: Atlantic salmon (Salmo salar) as a case study. Rev. Aquacult. doi: 10.1111/raq.12092

Brown, M.B. \& Forsythe, A.B. (1974). Robust tests for the equality of variances. J. Am. Stat. Ass. 69, 364-7.

Dala-Corte, R. \& Azevedo, M.A. (2010). Biologia reprodutiva de Astyanax henseli (Teleostei, Characidae) do curso superior do rio dos Sinos, RS, Brasil. Iheringia Ser. Zool. 100, 259-66.

De Carvalho, P., Paschoalini, A., Santos, G., Rizzo, E. \& Bazzoli, N. (2009). Reproductive biology of Astyanax fasciatus (Pisces: Characiformes) in a reservoir in southeastern Brazil. J. Appl. Ichthyol. 25, 306-13.

de Siqueira-Silva, D.H., dos Santos Silva, A.P., NinhausSilveira, A. \& Veríssimo-Silveira, R. (2015). The effects of temperature and busulfan (Myleran) on the yellowtail tetra Astyanax altiparanae (Pisces, Characiformes) spermatogenesis. Theriogenology 84, 1033-42.

dos Santos, M.P., Yasui, G.S., Xavier, P.L. P., de Macedo Adamov, N.S., do Nascimento, N.F., Fujimoto, T., Senhorini, J.A. \& Nakaghi, L.S.O. (2016). Morphology of gametes, post-fertilization events and the effect of temperature on the embryonic development of Astyanax altiparanae (Teleostei, Characidae). Zygote 24, 795-807.

Dunham, R.A. (2004). Aquaculture and Fisheries Biotechnology: Genetic Approaches. GABI Publishing, Oxford.

Feindel, N.J., Benfey, T.J. \& Trippel, E.A. (2010). Competitive spawning success and fertility of triploid male Atlantic cod (Gadus morhua). Aquacult. Environ. Interactions 1, 4755.
Feindel, N.J., Benfey, T.J. \& Trippel, E.A. (2011). Gonadal development of triploid Atlantic Cod Gadus morhua. J. Fish Biol. 79, 1900-12.

Felip, A., Piferrer, F., Carrillo, M. \& Zanuy, S. (2001). Comparison of the gonadal development and plasma levels of sex steroid hormones in diploid and triploid sea bass, Dicentrarchus labrax L. J. Exp. Zool. A Ecol. Genet. Physiol. 290, 384-95.

Fujimoto, T., Yasui, G.S., Yoshikawa, H., Yamaha, E. \& Arai, K. (2008). Genetic and reproductive potential of spermatozoa of diploid and triploid males obtained from interspecific hybridization of Misgurnus anguillicaudatus female with M. mizolepis male. J. Appl. Ichthyol. 24, 430-7.

Galvão, G.A., Silva, A.L.B., Cardoso, A.S., da Silva Santos, H., Pereira, P.A.N. \& Ribeiro, L.B. (2016). Histomorfometria gonadal comparada de Astyanax lacustris (Lütken, 1875) e Psellogrammus kennedyi (Eigenmann, 1903) (Characiformes, Characidae) em um reservatório no semiárido brasileiro. Boletim do Instituto de Pesca 42, 734-749.

Garutti, V. (2003). Piscicultura Ecológica, UNESP.

Golpour, A., Siddique, M.A. M., Siqueira-Silva, D.H. \& Pšenicka, M. (2016). Induced sterility in fish and its potential and challenges for aquaculture and germ cell transplantation technology: a review. Biologia 71, 853-64.

Haffray, P., Bruant, J.-S., Facqueur, J.-M. \& Fostier, A. (2005). Gonad development, growth, survival and quality traits in triploids of the protandrous hermaphrodyte gilthead seabream Sparus aurata (L.). Aquaculture 247, 107-17.

Hamasaki, M., Takeuchi, Y., Miyaki, K. \& Yoshizaki, G. (2013). Gonadal development and fertility of triploid grass puffer Takifugu niphobles induced by cold shock treatment. Mar. Biotechnol. 15, 133-44.

Han, Y., Liu, M., Lan Zhang, L., Simpson, B. \& Xue Zhang, G. (2010). Comparison of reproductive development in triploid and diploid female rainbow trout Oncorhynchus mykiss. J. Fish Biol. 76, 1742-50.

Huergo, G.M. \& Zaniboni-Filho, E. (2006). Triploidy induction in jundia, Rhamdia quelen (Quoy \& Gaimard, 1824), through hydrostatic pressuere shock. J. Appl. Aquacult. 18, 45-57.

Linhart, O., Rodina, M., Flajshans, M., Mavrodiev, N., Nebesarova, J., Gela, D. \& Kocour, M. (2006). Studies on sperm of diploid and triploid tench, Tinca tinca (L.). Aquacult. Internat. 14, 9-25.

Nascimento, N.F., Pereira-Santos, M., Piva, L.H., Manzini, B., Fujimoto, T., Senhorini, J. A., Yasui, G.S. \& Nakaghi, L.S.O. (2017). Growth, fatty acid composition, and reproductive parameters of diploid and triploid yellowtail tetra Astyanax altiparanae. Aquaculture 471, 163-71.

Okutsu, T., Shikina, S., Kanno, M., Takeuchi, Y. \& Yoshizaki, G. (2007). Production of trout offspring from triploid salmon parents. Science 317, 1517.

Peruzzi, S., Rudolfsen, G., Primicerio, R., Frantzen, M. \& Kauric, G. (2009). Milt characteristics of diploid and triploid Atlantic cod (Gadus morhua L.). Aquacult. Res. 40, $1160-9$.

Piferrer, F., Beaumont, A., Falguiere, J.-C., Flajshans, M., Haffray, P. \& Colombo, L. (2009). Polyploid fish and shellfish: Production, biology and applications to aquaculture for performance improvement and genetic containment. Aquaculture 293, 125-56. 
Porto-Foresti, F., Castilho-Almeida, R.B., Senhorini, J.A. \& Foresti, F. (2010). Biologia e criação do lambari do rabo amarelo (Astyanax altiparanae). In Espécies nativas pará piscicultura no Brasil, vol. 1 (eds B. Baldisserotto \& L.C. Gomes), pp. 101-15. Editora UFSM, Santa Maria, Brazil.

Quagio-Grassiotto, I., Grier, H., Mazzoni, T.S., Nobrega, R.H. \& Amorim, J.P.D. (2011). Activity of the ovarian germinal epithelium in the freshwater catfish, Pimelodus maculatus (Teleostei: Ostariophysi: Siluriformes): germline cysts, follicle formation and oocyte development. J. Morphol. 272, 1290306.

Schulz, R.W., de Franca, L.R., Lareyre, J.-J., LeGac, F., Chiarini-Garcia, H., Nobrega, R.H. \& Miura, T. (2010). Spermatogenesis in fish. Gen. Comp. Endocr. 165, 390411.
Taranger, G.L., Carrillo, M., Schulz, R.W., Fontaine, P., Zanuy, S., Felip, A., Weltzien, F.-A., Dufour, S., Karlsen, O., Norberg, B., Andersson, E. \& Hausen, T. (2010). Control of puberty in farmed fish. Gen. Comp. Endocrinol. 165, 483515.

Tiwary, B., Kirubagaran, R. \& Ray, A. (2000). Gonadal development in triploid Heteropneustes fossilis. J. Fish Biol. 57, 1343-8.

Yamaha, E., Saito, T., Goto-Kazeto, R. \& Arai, K. (2007). Developmental biotechnology for aquaculture, with special reference to surrogate production in teleost fishes. J. Sea Res. 58, 8-22.

Yasui, G.S., Santos, M. P., Nakaghi, L.S.O., Senhorini, J. A., Arias-Rodriguez, L., Fujimoto, T., Shimoda, E. \& Silva, L.A. (2015). Improvement of gamete quality and its shortterm storage: an approach for biotechnology in laboratory fish. Animal 9, 464-70. 